\title{
Selenium in long term feeding and the frequency of White Muscle Disease in cattle in Finland during the years 1978-1985
}

\author{
HAKON W. WESTERMARCK \\ Department of Pharmacology and Toxicology, College of Veterinary Medicine, SF-00551 \\ Helsinki, Finland
}

\begin{abstract}
Selenium deficiency was established in 1961 as the primary cause for WMD in Finland. This started the propylactic treatment with mineral salts containing $0.1 \mathrm{ppm}$ Se as Sodium selenite in Finland officially in 1969, the first in the world. The incidents of WMD decreased from $1.06 \%$ in 1978 to $0.66 \%$ in 1984. If in heifers only from 18907 cases, $7.9 \%$ to 11328 cases, $4.6 \%$, in 1984 .

The decrease of WMD cases reflects a better Se status in cattle as a whole, and has also contributed to an increase in the Se content in animal products. Even though Se insufficiency was established to be important for animals, the significance of Se for human beings was disregarded, until the consequences of the deficiency in man was demonstrated by $\mathrm{T}$. Westermarck in 1977.
\end{abstract}

Index words: Selenium, White Muscle Disease.

Hardly any other condition in cattle looks more similar to a serious neglection of the maintenance and feeding, than does the White Muscle Disease (WMD). Only a veterinarian is competent to judge, whether the animal in question should get medical treatment or should be taken care of by an inspector for the protection of animals. This is one of the many examples, where the veterinarian is the key person as to the protection of animals.

\section{Selenium (Se) deficiency and White Muscle Disease (WMD) in cattle}

The WMD is a myodegeneration disease most frequent in ruminants. It affects both skeletal and cardiac muscles in animals with Se-deficient diet.

In 1961-1962 Se-deficiency was shown to be the primary cause of WMD in the Finnish cattle, when the prophylactic effect of Sesupplementation to the cattle feed was established in more than one hundred herds with WMD problems. In the trial altogether 384 heifers in these herds were given Vasa Mill mineral salt containing $0.1 \mathrm{ppm}$ Se as sodium selenite and 586 heifers formed the control group. The following year the later group was provided with the Se-mineral salt, which resulted in a decrease in the WMD incidents 
from 17.6. percent to $0.5 \%$. The other group was left without the Se-supplementation and the WMD frequency increased nearly tenfold (Westermarck 1964).

Since 1969 the use of $10 \mathrm{ppm} \mathrm{Se}$, usually as sodium selenite, has been officially approved in mineral salts for cattle in Finland as the first country in the world. In feed compounds the Se-supplementation has been 0.1 ppm and in protein concentrates $0.56 \mathrm{ppm}$. whole country during 1978-1985 varied between $357 \mathrm{~kg}$ and $410 \mathrm{~kg}$ per year. In the control herds in the coastal area 68708 animals consumed $59.6 \mathrm{mg} \mathrm{Se} / \mathrm{Scand}$. feed unit per animal, and 82946 animals in the interior consumed only $27.8 \mathrm{mg} \mathrm{Se} / \mathrm{Scand}$. feed unit per animal in 1985. In spite of this the WMD incidents were $42.75 \%$ higher in the coastal area than in he interior when starting this study, and still $35.2 \%$ higher in 1985 . Even

Table 1. The Use of Selenium in Animal Feed During This Study.

\begin{tabular}{lrrrrrrr}
\hline & 1979 & 1980 & 1981 & 1982 & 1983 & 1984 & 1985 \\
\hline Sodium selenite $(\mathrm{kg})$ & 2200 & 2300 & 2700 & 2900 & 2400 & 3400 & 4000 \\
Pure selenium $(\mathrm{kg})$ & 99 & 104 & 122 & 131 & 108 & 153 & 180 \\
\hline
\end{tabular}

The WMD incidents in Various Parts of Finland During 1978-1985.

During 1978 - 1985 the number of cattle decreased in Finland continuously: cows from 742000 to 614000 , heifers from 237000 to 220000 , and calves from 701000 to 612000 .

In this study a frequency comparison was made between two areas: the coastal area and the interior area. The coastal area consisted of two counties, Vaasa and Oulu, situated along the North-West coast of the Gulf of Botnia, and the interior area covering the central Finland excluding the above mentioned coastal area.

In the interior area the number of cattle decreased from 220000 to 185000 and in the coastal area from 210000 to 191000 during the time of this study. At the same time the number of heifers in the coastal area decreased from 75000 to 61000 and in the interior from 62900 to 56600 . In 1978 the WMD was treated in $0.37 \%$ of all young animals, e.g. heifers and calves in the interior area, but nearly twice as much eg. $0.68 \%$, in the coastal area. The actual number of animals suffering from WMD is best elucidated by the percentage of treated WMD cases.

\section{The effect of Se supplementation}

The amount of Se fed to animals in the after a summer with a rainfall of $137.8 \mathrm{~mm} /$ month in the interior, there was a lower frequency of WMD than in the coastal area where the rainfall was only $103,8 \mathrm{~mm} / \mathrm{month}$. The higher incidence of WMD in the coastal area cannot be explained to be caused only by a Se-deficiency or a high rainfall.

In 1978 when this study started veterinarians treated 18907 cases of WMD in Finland, which gave incidents of $1.06 \%$. As the WMD mostly occurs in heifers and if heifers only are taken into consideration the incidents is $7.98 \%$. In the coastal area the incidents in heifers is then $13.1 \%$ and in the interior area $7.5 \%$.

The intensified Se-supplementation to cattle in a continuous frequency decrease of WMD in cattle. Thus in 1984 the WMD had to be treated by veterinarians in 11328 cases only, and the incidents dropped to $0.68 \%$. The incidents dropped more in the coastal area (4.6 $\%$ ) than in the interior $(1.4 \%)$.

According to ANDERSSON (1960) and OKSANEN (1965) the WMD frequency was much higher in the coastal area of the North West Finland than in the interior, and occured mostly in heifers. The difference between the high incidence of the WMD in the coastal area and that of the interior has however diminished owing to the increased use of mineral feeds containing Se, but does still exist to a certain degree. 
Table 2. Incidents of the White Muscle Disease, WMD, in Cattle in the years 1978-1985.

\begin{tabular}{|c|c|c|c|c|c|c|c|c|}
\hline Year & 1978 & 1979 & 1980 & 1981 & 1982 & 1983 & 1984 & 1985 \\
\hline $\begin{array}{l}\text { Number of WMD } \\
\text { cases }\end{array}$ & 18907 & 16763 & 15341 & 14206 & 12514 & 12300 & 11328 & 10585 \\
\hline $\begin{array}{l}\text { Number of } \\
\text { cattle }(1000)\end{array}$ & 1779 & 1736 & 1738 & 1766 & 1719 & 1588 & 1658 & 1608 \\
\hline $\begin{array}{l}\text { Incident } \% \\
\text { of WMD }\end{array}$ & $1.06 \%$ & $0.97 \%$ & $0.88 \%$ & $0.77 \%$ & $0.70 \%$ & $0.77 \%$ & $0.68 \%$ & $0.66 \%$ \\
\hline $\begin{array}{l}\text { Number of } \\
\text { cows (1000) }\end{array}$ & 742 & 730 & 719 & 700 & 689 & 658 & 642 & 614 \\
\hline $\begin{array}{l}\text { Incident } \% \text { of } \\
\text { WMD if exclusive } \\
\text { in cows }\end{array}$ & $2.5 \%$ & $2.3 \%$ & $2.1 \%$ & $2.0 \%$ & $1.8 \%$ & $1.9 \%$ & $1.8 \%$ & $1.7 \%$ \\
\hline $\begin{array}{l}\text { Number of } \\
\text { heifers }(1000)\end{array}$ & 237 & 238 & 233 & 253 & 224 & 213 & 234 & 220 \\
\hline $\begin{array}{l}\text { Incident } \% \text { of } \\
\text { WMD if exclusive } \\
\text { in heifers }\end{array}$ & $7.98 \%$ & $7.03 \%$ & $6.6 \%$ & $5.6 \%$ & $5.6 \%$ & $5.8 \%$ & $4.8 \%$ & $4.8 \%$ \\
\hline $\begin{array}{l}\text { Selenium }(\mathrm{Se}) \\
1000 \mathrm{~kg} / \text { year }\end{array}$ & 40.430 & 41.038 & 42.311 & 37.459 & 37.626 & 37.853 & 37.751 & \\
\hline $\begin{array}{l}\text { In cattlefeed } \\
10 \mathrm{mg} / \mathrm{kg}\end{array}$ & 404 & 410 & 423 & 375 & 376 & 378 & 375 & \\
\hline $\begin{array}{l}\text { Se mg/day/animal } \\
\text { indoors ( } 240 \text { days) }\end{array}$ & 0.94 & 0.98 & 1.01 & 0.88 & 0.91 & 0.99 & 0.94 & \\
\hline Se kg/year/animal & 0.23 & 0.24 & 0.24 & 0.21 & 0.22 & 0.24 & 0.23 & \\
\hline $\begin{array}{l}\text { Se as injections } \\
\text { ca. g/year } \\
\text { on Myoselen basis } \\
\text { Fertilizer million }\end{array}$ & 227 & 200 & 184 & 170 & 150 & 148 & 137 & 127 \\
\hline $\begin{array}{l}\text { kg (July-December) } \\
\text { Fertilizer } 6 \text { mg Se } \\
\text { per kg }\end{array}$ & & & & & & & 169 & 245 \\
\hline
\end{tabular}

Se in milk $19750.017-0.030 \mathrm{ppm} \quad 1976$ : indoors $0.034 \mathrm{ppm}$, pasture $0.022 \mathrm{ppm}$,

1986: indoors $0.027 \mathrm{ppm}$ pasture $0.008 \mathrm{ppm}$

The acidity of the soil and perhaps other factors such as high iron and sulphur contents have certainly an influence on the available of selenium to animals and have to be taken into consideration as the cause for the susceptibility to the White Muscle Disease. The sharp decrease of the WMD in the whole country shows that the Se level has improved. However, it has to be kept in mind that selenium salts and especially organic selenium compounds are extremely toxic. The National Research Council (1980) considers that $2 \mathrm{mg}$ $\mathrm{Se} / \mathrm{kg}$ Dry Matter is the maximum concentration tolerable for all species. Also it is claimed, that monogastric animals can tolerate selenium compounds better than ruminants do.

\section{Summary}

Selenium deficiency was established in 1961 - 62 as the primary cause for the White Muscle Disease, WMD, in Finland. This started the prophylactic treatment of the disease with mineral salts containing $0.1 \mathrm{ppm}$ Se as sodium selenite, which was approved in Finland as the first country in the world officially in 1969.

This resulted in a continuous decrease in the incidents of the WMD during the period of this study 18907 cases eg. 1.06 percent in 1978 to 11328 cases eg. 0.66 percent in 1984 . If the WMD had occurred only in heifers the incidents had dropped from 7.9 percent to 4.6 percent during the same period. 
As the number of cattle in Finland decreased during the same period from 742000 to 614000 and the heifers from 237000 to 220000 the frequency of WMD is more significant than the actual number of cases.

The decrease in the frequency of WMD in cattle reflects a better status in the supply of selenium and has contributed to an increase in the selenium content in animal products. The difference between the incidents of WMD in the coastal area and the interior is, however, dependant also on other factors than selenium deficiency only.

\section{References}

ANDERSSON, P. 1960. Nutritional muscular dystrophy in cattle with special reference to the functional state of the thyroid. VMD Diss. College of Veterinary Medicine, Helsinki.

Gissel-Nielsen, G. 1976. Selenium in soils and plants. Proc. Symp. Selenium Tellurium in the environment 1976.

Kivinen, E. 1944. Sulfat- eller alunjordar, deras egenskaper och synpunkter på deras odling. Svenska Valloch Mosskultur Tidskr. 2: 1.

Oksanen, H. 1965. Studies on nutritional muscular degeneration NMD in ruminants. VMD Diss. College of Veterinary Medicine, Helsinki.

Schwartz, K. \& K.D. PathaK, 1975. The biological essentially of selenium and the development of biologi-

\section{REFERAT}

\section{Selen utfodringens betydelse för frekvensen av vaxartad muskeldegeneration på nöt $\mathrm{i}$ Finland under åren 1978-1985}

Hakon W. Westermarck

Under åren 1961 - 62 konstaterades att den vaxartade muskeldegenerationen på nöt i Finland kunde hänföras till selenbrist. Detta ledde till att en profylax med selenhaltig mineral med $0.1 \mathrm{ppm}$ Se i form av natrium selenit infördes. Finland var det första land där selentillskottet i denna form godkändes officielt, år 1969.

Användningen av selen mineral ökade år för år och ledde till att frekvensen av den vaxartade muskeldegeneration i hela landet minskade från år 1978 med 18977 fall (1.06\%) till 11328 fall år $1984(0.66 \%)$, den kontinuerligt sjunkande frekvensen har f.ö. fortsatt och tendensen har inte förändrats påtagligt av senare insatt gödsling med selen. Under år 1986 konstaterades 9376 fall av muskeldegeneration på nöt och kornas antal var 599100 och kvigornas antal 168700.
Even though selenium deficiency was established to be an important nutritional deficiency in animals, the significance of selenium deficiency for human beings was disregarded, until the status in Finnish people and the consequences of the deficiency in man was demonstrated by T. Westermarck in 19771979.

Selenium salts and especially organic selenium compounds are, however, extremely toxic and the status of selenium reached in Finland cannot be exceeded, without serious consequences.

cally active organoselenium compounds of minimum toxicity. Chem. Scripta 8, p 85-95.

Westermarck, H. 1964. Selenium in prevention and therapy in White Muscle Disease in calves and heifers. Nord. Vet. Med. 16: 264-274.

Westermarck, T., P. Raunu and L. Lappalainen, 1977. Selenium content of whole blood and serum in adults and children of different ages from different parts of Finland. Acta Pharmacol. Toxicol. 40: 465-475.

Westermarck, T. 1979. Studies on selenium status in the Finnish population with special reference to patients with neuronal ceroid lipofuscinosis. MD Diss. University of Helsinki.

Ms received February 5, 1987
Under perioden 1978-1985 sjönk antalet nötkreatur i landet från 742000 till 614000 och antalet kvigor från 237000 till 220000 . Detta gör att frekvensen av muskeldegeneration ger en băttre bild av förhållandena ăn antalet fall per år.

Den sjunkade frekvensen av muskeldegeneration återspeglar en förbăttrad tillförsel av selen till nötkreaturen och bidrar till en högre halt av selen $\mathrm{i}$ animalie produkterna. Skillnaden mellan frekvensen av muskeldegeneration i kustområdena och det inre av landet, trots tillförseln av selen visar att även andra faktorer än selenbrist spelar en roll vid uppkomsten av muskeldegeneration pá nöt.

Även om betydelsen av ett selentillskott för djurens hälsa redan tidigt vann burskap inom veterinärmedicinen i Finland ignorerades selenets betydelse för människan, tills T. Westermarck's undersökningar under åren 19771979 påvisade detta spårelements betydelse. Selensalten och sărskilt då selen i organisk form är extremt toxiska och năr optimalt selenstatus uppnåtts $\mathrm{i}$ vårt land kan ytterlig tillförsel medföra allvarliga konsekvenser. 